UDC 539.3

\title{
MODAL ANALYSIS OF A COMPLEX SHELL STRUCTURE UNDER OPERATIONAL LOADS
}

\author{
V.A. Bazhenov, \\ Doctor of Technical Science \\ O.P. Krivenko, \\ Candidate of Science (Engineering) \\ A.A. Kozak, \\ Candidate of Science (Engineering) \\ Kyiv National University of Construction and Architecture \\ 31, Povitroflotsky ave., Kyiv, Ukraine, 03037
}

DOI: $10.32347 / 2410-2547.2021 .106 .5-13$

\begin{abstract}
The results of calculation of a complex shell structure under the action of operational loads are presented. A three-section cooling tower, called a three-petal cooling tower, is regarded as a complex-shaped structure. Three variants of loads on the shell are considered: wind pressure, heating and load combination. The design model of a shell of a complex shape is based on the developed universal spatial finite element. The universal spatial finite element allows one to take into account the geometric features of structural elements for a thin shell (constant or varying thickness, knees, ribs, cover plates, holes, cavities, channels, inserts, facets) and multilayer structure of the material. According to the method, thin and medium thickness shells of various shapes and structures are considered. The shells are under the action of static mechanical and temperature loads. The finite element method is based on the unified positions of the threedimensional geometrically nonlinear theory of thermoelasticity and the moment finite element scheme. The method for determining the natural vibrations of thin-walled shell structures is based on an integrated approach. Modal analysis is carried out taking into account the prestressed and deformed states of the shell at each step of thermomechanical loading. Thus, the problem of determining the natural frequencies and vibration modes of the shell is solved by the step method in two stages.
\end{abstract}

Keywords: elastic shell, universal finite element, thermo-mechanical load, stress-strain state, natural frequency, mode shapes.

\section{Introduction}

Shells, as flexible thin-walled elements of increased strength, are widely used in engineering structures in many industries: from space to construction. Thin-walled shell structures of special equipment can have an almost inexhaustible variety of geometric shapes, based on their functional purpose. They can combine various structural inhomogeneities, such as: ribs and cover plates, reinforced and non-reinforced holes, cavities, channels, local thickenings and thinning, knees of the midsurface and other features, as well as have a complex shape. The behavior of such structures has not been studied enough due to the complexity of taking into account all these factors when constructing governing equations. Thin-walled shell structures can be in 
difficult operating conditions under the action of loads of various natures, including mechanical and thermal ones.

Most of the methods for studying thin-walled structures are focused on a relatively limited class of shells, predominantly of canonical form, and simple loading processes, mainly mechanical. Therefore, methods of numerical analysis, primarily the finite element method, are widely used to solve various problems in the study of shell structures [1-6]. The complication of the geometric shape, which actually occurs in every real shell structure, requires the use of refined approaches from the standpoint of the three-dimensional theory of thermoelasticity and the development of 3-d finite elements on this basis. The use of a three-dimensional approach for the study of thin shells has recently been considered in an increasing number of works [3, 4, 7-12] in accordance with global trends in problem solving.

Based on modern approaches to solving this problem, the authors have been carrying out theoretical and practical developments for many years in the direction of creating methods for analyzing the reactions of thin-walled structures to complex thermo-mechanical effects. A finite element method has been developed for studying processes of geometrically nonlinear deformation, buckling, post-buckling behavior, and vibrations of thin thermoelastic inhomogeneous shells with complex-shaped midsurface, geometrical features throughout the thickness under complex thermo-mechanical loading. A number of tasks have been solved. The features of thermoelastic deformation, buckling, post-buckling behavior, and vibrations of thin shells under the action of static thermo-mechanical loads have been identified and analyzed [7-10, 13-16].

This paper is a continuation of previous studies and is aimed at modal analysis of shell structures of complex shape under the action of operational loads.

\section{Problem statement}

The technique for studying the behavior of thin-walled shell structures of a complicated geometric shape is based on the use of the finite-element shell model (FESM) of an inhomogeneous shell and is presented in articles [7$10,16]$. The design model is based on the developed universal spatial finite element. The geometric features of structural elements for a thin shell (constant or varying thickness, knees, ribs, cover plates, holes, cavities, channels, inserts, facets, etc.) and multilayer structure of its material are taken into account. Thin and medium thickness shells of various shapes and structures are considered under the static action of mechanical and temperature loads. The method is created on the basis of the unified positions of the threedimensional geometrically nonlinear theory of thermoelasticity and the finite elements moment scheme.

As an example of determining the modal characteristics of a shell structure of a complex shape, a three-section cooling tower, called a "three-petal cooling tower" $[17,18]$, is considered. The cooling tower is a three-dimensional combined system consisting of a thin reinforced concrete three-section shell 
and an inclined colonnade. The lower part of the colonnade is rigidly clamped into the ring foundation.

The three-section structure consists of the shells of three cooling towers and it belongs to the unique structures in many respects (Figure 1). Its dimensions: height $-110 \mathrm{~m}$, semi-axes of the ellipse at the base of the petal $70.77 \mathrm{~m}$ and $25.08 \mathrm{~m}$, thickness at the base $-0.7 \mathrm{~m}$, thickness in the narrow part $-0.2 \mathrm{~m}$. Each cooling tower petal is a complex shell. It is an elliptical cone with a linear-variable thickness at heights from 10 to $100 \mathrm{~m}$. In the narrow part (between heights of $100 \mathrm{~m}$ and $110 \mathrm{~m}$ ) it is an elliptical cylinder of constant thickness $0.2 \mathrm{~m}$. The observation deck with $1 \mathrm{~m}$ wide is mounted above the narrow part of the cooling tower. This platform is modeled as a rib in the finite element model of the shell. Internal cooling tower diaphragms are considered to be quite rigid. They have not been considered as elastic elements of the cooling tower and, for simplicity, have been taken into account as rigid ties. The exhaust shell of the cooling tower is supported on an inclined colonnade at a height of $10 \mathrm{~m}$. The colonnade is fixed on a rigid base plate. When forming the FESM, it has been assumed that the shell is rigidly clamped at a height of $10 \mathrm{~m}$ (Figure 2). Therefore, support columns were not included in the model.

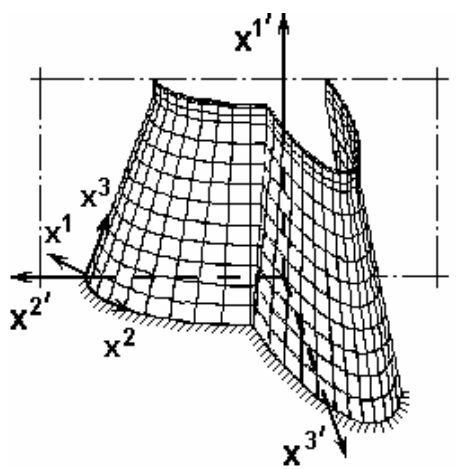

(a)

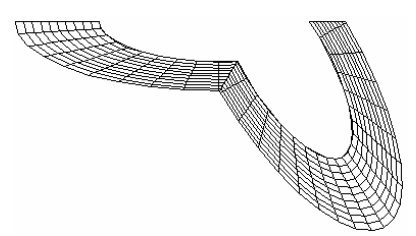

(b)

Fig. 2. Design finite element model of a cooling tower:

(a) side view, (b) top view in the plane $x^{2^{\prime}} x^{3^{\prime}}$

During operation, the cooling tower is subjected to wind pressure and temperature field. In the computation, these loads are taken as static. 
Temperature effects on the shell are caused by technological heating and seasonal fluctuations in the outside air temperature. Three variants of the loads acting on the shell have been accepted: (i) uniform heating of the shell by $30^{\circ} \mathrm{C}$, (ii) wind pressure, and (iii) combination of both loads.

\section{Results of modal analysis}

The stages of the formation of the FESM of a three-petal cooling tower are presented in detail in $[86, * 100]$. At the first stage of the computations, the stress-strain state of the structure from the impact of the applied operational loads has been analyzed. Based on the analysis of the observed results, the following conclusions can be drawn.

Deformation analysis. The grid of the cooling tower deformed from the action of loads and their top view are shown in Fig. 3. It can be seen that the side walls of the cooling tower are bent inside the FESM due to the wind load and the combination of loads. With uniform heating, the sidewalls of the cooling tower bend outward.
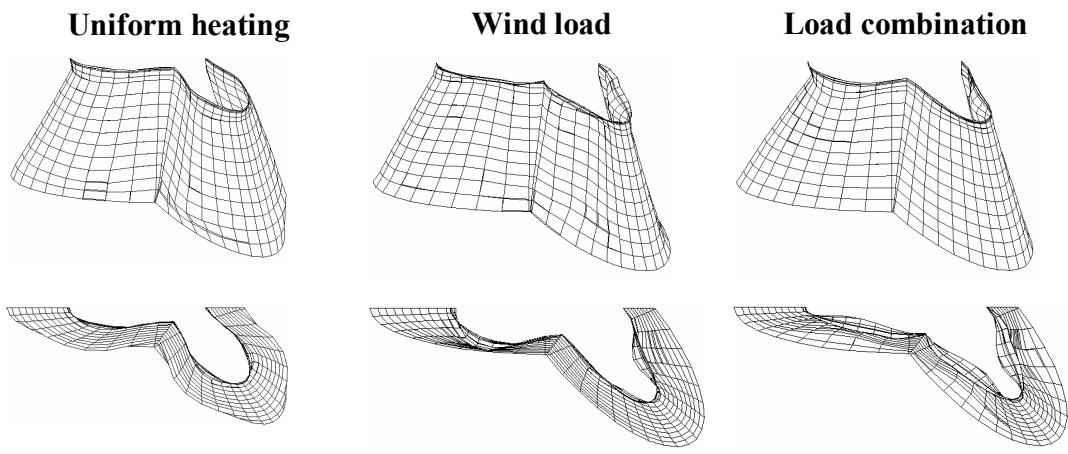

Fig. 3. Deformation shapes of the FESM under various thermo-mechanical loads

Stress analysis. The stress state of the cooling tower from the action of operational loads can be estimated by the obtained moiré fringes of bending and membrane stresses (Fig. 4). With uniform heating, the maximum bending stresses occurs at the bottom on the sides of the conical part of the petal, the minimum stresses are located at the bottom of the joint of the petals. The maximum membrane stresses are on the sides of the petals at the bottom of the structure, nearer to the joint. The wind load creates the maximum bending stresses at the top of the conical part of the petal, the maximum membrane stresses are at the bottom of the fracture of the petals. When there is a combination of loads, the maximum bending and membrane stresses are obtained in the support zone of the side parts of the petals. When there is a combination of loads, maximum bending and membrane stresses have been obtained in the petal support zone.

At the second stage of the research, a modal analysis of the structure has been carried out. The effect of operation loads on natural frequencies and 
modes of vibration has been investigated. The comparison has been carried out with the dynamic characteristics of the structure, which is in a load-free state.

Heating and the action of wind load had little effect on the change in vibration frequencies relative to the unloaded state (less than $1 \%$, Table 1). The vibration modes accordingly also changed a little bit. The combination of loads led to an increase in first four natural frequencies, respectively by 34.33 , $28.65,39.03$, and $43.08 \%$. The vibration modes are shown in Fig. 5. Here (a) is the initial unstressed state of the cooling tower; (b) is the effect of a combination of two loads.
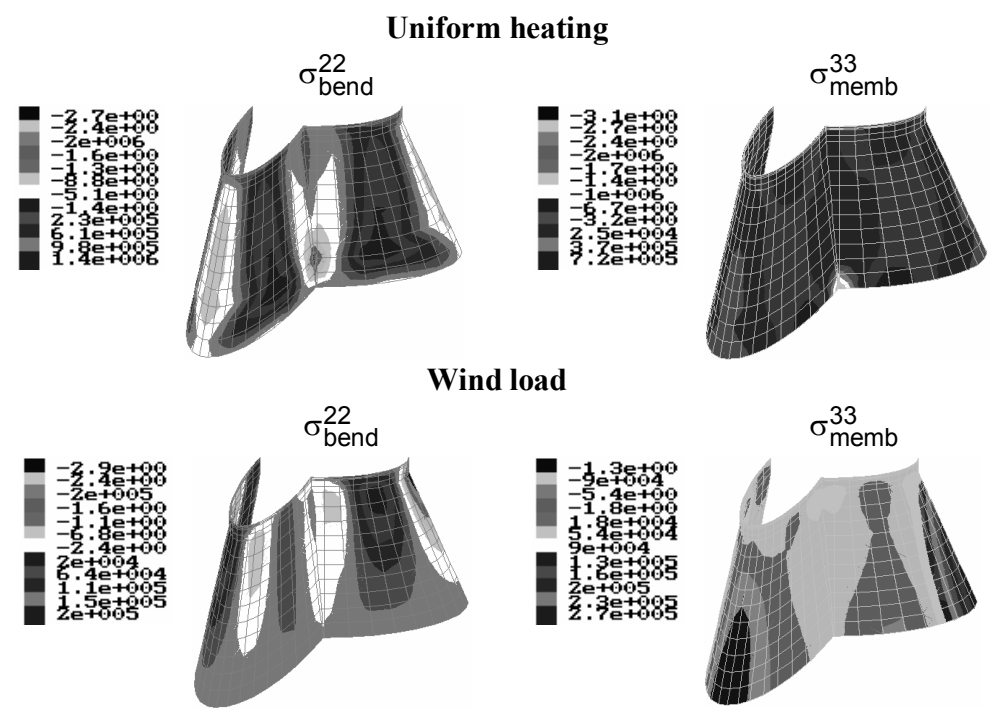

Load combination

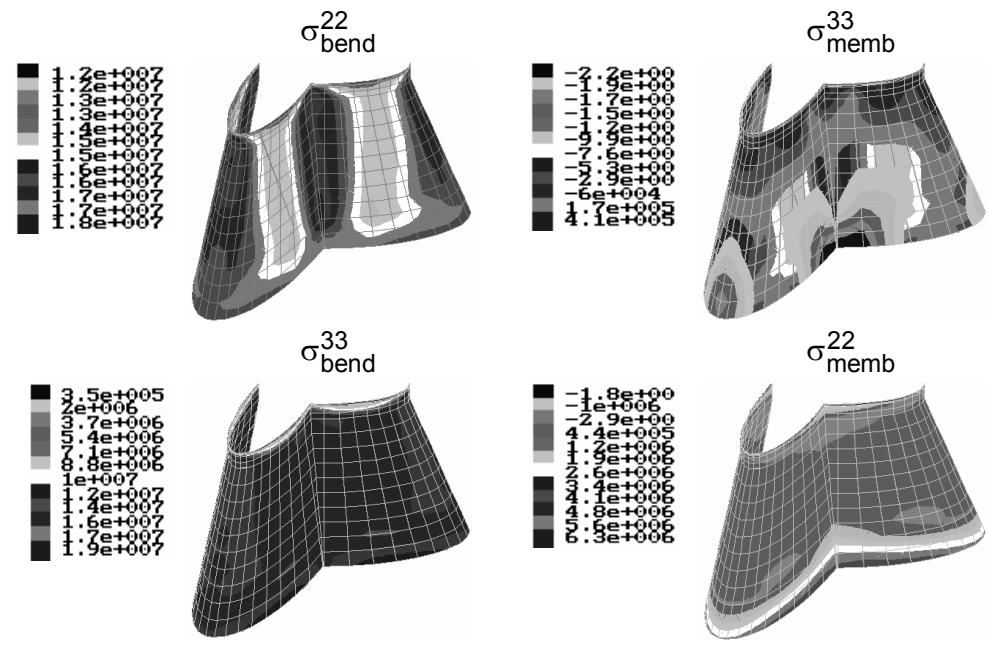

Fig. 4. Visualization of stresses using moiré fringes 


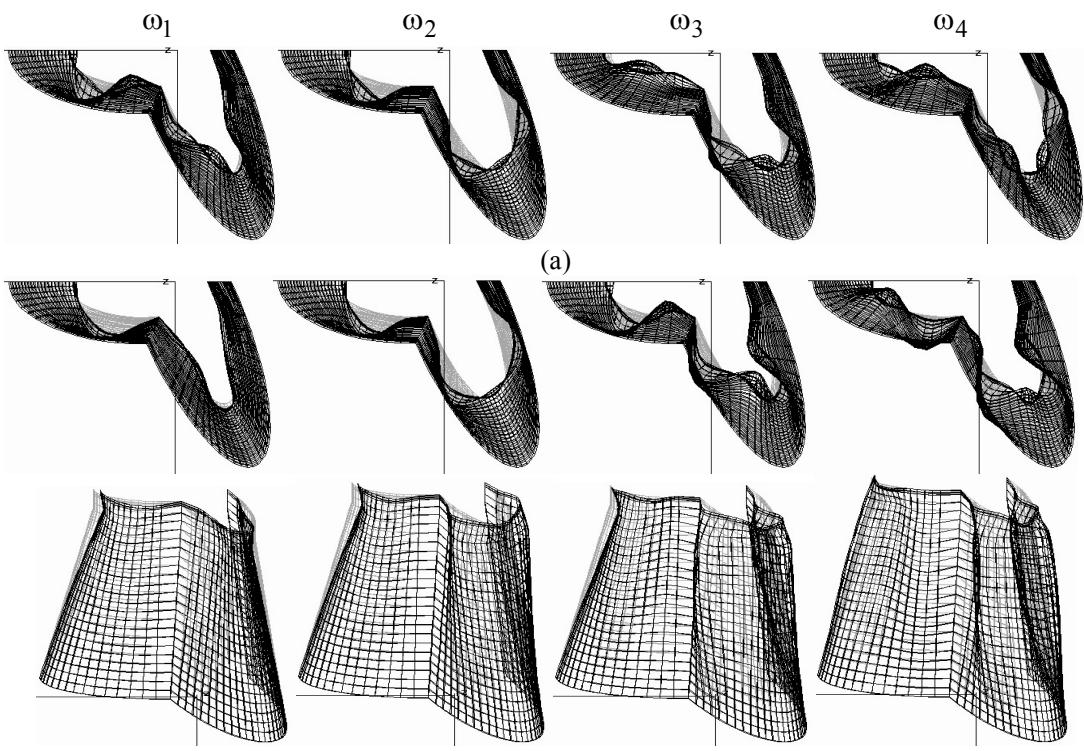

(b)

Fig. 5. Vibration modes of the cooling tower: (a) initial state; (b) load combinations

Table 1

\begin{tabular}{|c|l|l|l|l|}
\hline Load & \multicolumn{1}{|c|}{$\omega_{1}$} & \multicolumn{1}{|c|}{$\omega_{2}$} & \multicolumn{1}{|c|}{$\omega_{3}$} & \multicolumn{1}{c|}{$\omega_{4}$} \\
\hline The initial state & 1.3491 & 1.4515 & 1.4661 & 1.6334 \\
\hline Uniform heating & 1.3513 & 1.4689 & 1.4777 & 1.6420 \\
& $0,16 \%$ & $1,20 \%$ & $0,79 \%$ & $0,53 \%$ \\
\hline Wind load & 1.3489 & 1.4498 & 1.4660 & 1.6320 \\
& $-0,01 \%$ & $-0,12 \%$ & $-0,007 \%$ & $-0,09 \%$ \\
\hline Load combination & 1.8123 & 1.8673 & 2.0384 & 2.3370 \\
& $34,33 \%$ & $28,65 \%$ & $39,03 \%$ & $43,08 \%$ \\
\hline
\end{tabular}

\section{Conclusions}

Investigation of the stress-strain state and modal analysis of the shell structure of complex shape and structure have been carried out. A threepetalcooling tower is considered which is under the action of operational loads. The effect of three types of load on the behavior of a cooling tower has been investigated: heating, wind effect, and a combination of the indicated loads. Investigations have shown the effectiveness of using the method for analyzing shells of complex shapes and structures in real operating conditions.

\section{REFERENCES}

1. Chapelle D., Bathe K.J. The finite element analysis of shells - Fundamentals. Series: Computational fluid and solid mechanics. - Berlin; Heidelberg: Springer, 2011 - 410 p. 
2. Reddy J.N. Theory and Analysis of Elastic Plates and Shells, Second Edition - CRC Press, 2006. -568 p.

3. Metod konechnyh elementov v mehanike tverdyh tel / A.S.Saharov, V.N.Kislookij, V.V.Kirichevskij $i d r$. - K.: Visha shk. Golovnoe izd-vo, 1982. - 480 s. [The finite element method in mechanics] (rus).

4. Golovanov A.I., Tyuleneva O.N., Shigabutdinov A.F. Metod konechnyh elementov v statike i dinamike tonkostennyh konstrukcij. - M.: FIZMATLIT, 2006. - 392 s. [The finite element method in the statics and dynamics of thin-walled structures] (rus).

5. Gureeva N.A., Klochkov Yu.V., Nikolaev A.P., Yushkin V.N. Stress-strain state of shell of revolution analysis by using various formulations of three-dimensional finite elements // Structural Mechanics of Engineering Constructions and Buildings, 2020. - 16(5). - P. 361-379.

6. Bischoff M., Ramm E., Irslinger J. Models and finite elements for thin-walled structures // Encyclopedia of Computational Mechanics Second Edition. - 2018. - P. 1-86.

7. Bazhenov V.A., Krivenko O.P., Solovey M.O. Neliniyne deformuvannya ta stiykist pruzhnih obolonok neodnoridnoyi strukturi. - K.: ZAT «Vipol», 2010. - 316 s. [Nonlinear deformation and stability of elastic shells with inhomogenous structure. Kyiv: CJSC "VIPOL”, 2010. - 316s.] (ukr).

8. Bazhenov V.A., Krivenko O.P., Solovey N.A. Nelineynoe deformirovanie i ustoychivost uprugih obolochek neodnorodnoy strukturyi: Modeli, metodyi, algoritmyi, maloizuchennyie i novyie zadachi. - M.: Knizhnyiy dom «LIBROKOM», 2013. - 336 s. [Nonlinear deformation and stability of elastic shells of inhomogeneous structure: Models, methods, algorithms, poorlystudied and new problems. - Moscow: publishing house "LIBROKOM", 2013. - 336 s.] (rus).

9. Bazhenov V., Krivenko O. Buckling and Natural Vibrations of Thin Elastic Inhomogeneous Shells. - LAP LAMBERT Academic Publishing. Saarbruken, Deutscland, 2018. - 97 p.

10. Solovey N.A., Krivenko O.P., Malygina O.A. Konechnoelementnye modeli issledovaniya nelinejnogo deformirovaniya obolochek stupenchato-peremennoj tolshiny $\mathrm{s}$ otverstiyami, kanalami i vyemkami [Finite element models for the analysis of nonlinear deformation of shells stepwise-variable thickness with holes, channels and cavities // Magazine of Civil Engineering, 2015. - No. 1. - Pp. 56-69.] (rus).

11. Yakupov S.N., Kiyamov I.H. Analiz NDS sfericheskikh obolochek trekhmernymi elementami [Analysis of the mode of deformation of spherical covers three-dimensional elements] // Structural Mechanics of Engineering Constructions and Buildings, 2014. - № 2. - P. 76-80. (rus)

12. Lekomtsev S.V. Konechno-elementnyye algoritmy raschota sobstvennykh kolebaniy trokhmernykh obolochek // Vychislitel'naya mekhanika sploshnykh sred. - 2012. - T. 5. - №. 2. - S. 233-243 [Finite-element algorithms for calculation of natural vibrations of threedimensional shells // Computational Continuum Mechanics, 2012. - Vol. 5. - Issue 2. - P. 233-243] (rus)

13. Krivenko O.P. Effect of static loads on the natural vibrations of ribbed shells // Strength of Materials and Theory of Structures: Scientific-and-technical collected articles. - K.: KNUBA, 2018. - Issue 101. - P. 38-44.

14. Bazhenov V.A., Krivenko O.P., Vorona Yu.V. Effect of heating on the natural vibrations of thin parabolic shells // Strength of Materials and Theory of Structures: Scientific-and-technical collected articles. - K.: KNUBA, 2019. - Issue 103. - P. 3-16.

15. Bazhenov V.A., Krivenko O.P. Buckling and vibrations of the shell with the hole under the action of thermomechanical loads // Strength of Materials and Theory of Structures: Scientific-and-technical collected articles - Kyiv: KNUBA, 2020. - Issue 104. - P. 136-146.

16. Bazhenov V.A., Solovei N.A., Krivenko O.P., Mishchenko O.A. Modelirovaniye nelineynogo deformirovaniya i poteri ustoychivosti uprugikh neodnorodnykh obolochek [Modeling of Nonlinear Deformation and Buckling of Elastic Inhomogeneous Shells] // Structural Mechanics of Engineering Constructions and Buildings, 2014. - Issue 5. - P. 14-33. (rus).

17. Gordon L.A., Zhunusov T.ZH., Itskov I.Ye., Korchinskaya O.A. Napryazhennoye sostoyaniye bashennykh gradiren pri real'nom opiranii // Beton i zhelezobeton, 1985. - N 9. - C. 11-12 [Stressed state of tower cooling towers under real support // Concrete and reinforced concrete, 1985. - Issue 9. - P. 11-12] (rus).

18. Korchinskaya O.A. Zhelezobetonnyye gradirni bol'shoy proizvoditel'nosti: konstruktivnyye osobennosti, napryazhennoye sostoyaniye: Avtoref. dis. ... kand. tekhn. nauk: 05.23 .01 / NII betona i zhelezobetona Gosstroya SSSR. - M., 1988. - 24 s. [Reinforced concrete cooling towers of high performance: design features, stress state: Avtoref. dis. ... Cand. tech. Sciences: 05.23.01 / Research Institute of concrete and reinforced concrete of the USSR State Construction Committee] (rus). 
Баженов В.А., Кривенко О.П., Козак А.А.

\section{МОДАЛЬНИЙ АНАЛІЗ СКЛАДНОЇ ОБОЛОНКОВОЇ КОНСТРУКЦІї, ЩО ЗНАХОДИТЬСЯ ПІД ДІЕЮ ЕКСПЛУАТАЦІЙНИХ НАВАНТАЖЕНЬ}

Наведено результати розрахунку деформування і коливань складної оболонкової конструкції під дією експлуатаційних навантажень. Трьохсекційна градирня, звана трипелюстковою градирнею, відноситься до тонкостінних конструкцій складної форми. Розглянуто три варіанти навантажень на оболонку: вітровий тиск, нагрів і поєднання навантажень. Розрахункова модель оболонки складної форми побудована за допомогою розробленого універсального просторового скінченного елемента. Універсальний просторовий скінченний елемент дозволяє врахувати геометричні особливості конструктивних елементів тонкої оболонки (стала або змінна товщина, злами, ребра, накладки, отвори, виїмки, канали, вставки, гранованість), а також багатошарову структуру матеріалу. За методикою розглядаються тонкі і середні товщини оболонки різної форми i структури. Оболонки знаходяться під дією статичних силових i температурних навантажень. Скінченноелементний метод створено на основі єдиних позицій просторової геометрично нелінійної теорії термопружності та моментної схеми скінченних елементів. Методика дослідження власних коливань тонкостінних оболонкових конструкцій 3 урахуванням дії статичного термосилового навантаження спирається на комплексний підхід. Модальний аналіз виконується 3 урахуванням попередньо напруженого та деформованого станів оболонки на кожному кроці ії термосилового навантаження. Таким чином задача 3 визначення власних частот і форм коливань оболонки розв'язується кроковим методом за два етапи.

Ключові слова: пружна оболонка, універсальний скінченний елемент, термосилове навантаження, напружено-деформований стан, власна частота, форма коливань.

Баженов В.А., Кривенко О.П., Козак А.А.

МОДАЛЬНЫЙ АНАЛИЗ СЛОЖНОЙ ОБОЛОЧЕЧНОЙ КОНСТРУКЦИИ, НАХОДЯЩЕЙСЯ ПОД ДЕЙСТВИЕМ ЭКСПЛУАТАЦИОННЫХ НАГРУЗОК

Приведены результаты расчета деформирования и колебаний сложной оболочечной конструкции под действием эксплуатационных нагрузок. Трехсекционная градирня, называемая трехлепестковой градирней, относится к тонкостенным конструкциям сложной формы. Рассмотрены три варианта нагрузок на оболочку: ветровое давление, нагрев и объединение нагрузок. Расчетная модель оболочки сложной формы построена на основе разработанного универсального пространственного конечного элемента. Универсальный пространственный конечный элемент позволяет учесть геометрические особенности конструктивных элементов тонкой оболочки (постоянная или переменная толщина, изломы, ребра, накладки, отверстия, выемки, каналы, вставки, граненность), а также многослойную структуру материала. Методика позволяет рассматривать тонкие и средние толщины оболочки различной формы и структуры. Оболочки находятся под действием статических силовых и температурных нагрузок. Конечноэлементный метод основан на единых позициях трехмерной геометрически нелинейной теории термоупругости и моментной схемы конечнох элементов. Методика определения собственных колебаний тонкостенных оболочечных конструкций основана на комплексном подходе. Модальный анализ проводится с учетом преднапряженного и деформированного состояний оболочки на каждом шаге ее термомеханического нагружения. Таким образом, задача определения собственных частот и форм колебаний оболочки решается шаговым методом в два этапа.

Ключевые слова: упругая оболочка, универсальный конечный элемент, термосиловая нагрузка, напряженно-деформированное состояние, собственная частота, форма колебаний.

\section{УДК 539.3}

Баженов В.А., Кривенко О.П., Козак А.А. Модальний аналіз складної оболонкової конструкції, що знаходиться під дією експлуатаційних навантажень // Опір матеріалів і теорія споруд: наук.-тех. збірник - К.: КНУБА, 2021. - Вип. 106. - С. 5-13. - Англ.

Досліджено вплив експлуатаційних навантажень на напружено-деформований стан $i$ коливання трипелюсткової градирні.

Табл. 1. Іл. 5. Бібліогр. 18 назв. 
UDC 539.3

Bazhenov V.A., Krivenko O.P., Kozak A.A. Modal analysis of a complex shell structure under operational loads // Strength of Materials and Theory of Structures: Scientific-and-technical collected articles. - K.: KNUBA, 2021. - Issue 106. - P. 5-13.

Effect of operating loads on the stress-strain state and vibrations of a three-petal cooling tower is investigated.

Tabl. 1. Fig. 5. Ref. 18.

Баженов В.А., Кривенко О.П., Козак А.А. Потеря устойчивости и колебания оболочки с отверстием под действием термосиловой нагрузки // Сопротивление материалов и теория сооружений: науч.-тех. сборн. - К.: КНУСА, 2021. - Вып. 106. - С. 5-13. - Англ.

Исследовано влияние эксплуатационных нагрузок на напряженно-деформированное состояние и колебания трехлепестковой градирни.

Табл. 1. Ил. 5. Библиогр. 18 назв.

Автор (вчена ступень. вчене звання. посада): доктор технічних наук, професор, завідувач кафедри будівельної механіки, директор НДІ будівельної механіки БАЖЕНОВ Віктор Андрійович

ORCID ID: https://orcid.org/0000-0002-5802-9848

Автор (вчена ступень, вчене звання, посада): кандидат технічних наук, старший науковий співробітник, провідний науковий співробітник НДІ будівельної механіки КНУБА КРИВЕНКО Ольга Петрівна

Адреса робоча: 03680 Украӥна, м. Київ, Повітрофлотський проспект 31, Київський національний університет будівництва і архітектури.

Робочий тел.: $+38(044)$ 245-48-29.

мобільний тел.: +38(066) 048-32-77

E-mail: olakop@ukr.net

ORCID ID: https://orcid.org/0000-0002-1623-9679

Автор: асистент кафедри будівельної механіки КНУБА КОЗАК Андрій Анатолійович; Адреса робоча: 03680, Київ, Украӥна, м. Київ, Повітрофлотський пр. 31, Київський національний університет будівництва і архітектури, КОЗАКУ Андрію Анатолійовичу;

Робочий тел.: +38(044)248-32-37;

Мобільний тел.: +38(066)199-70-36;

E-mail: kozak.aa@knuba.edu.ua

ORCID ID: https://orcid.org/0000-0002-3192-1430 